\title{
The iron isotope compositions of komatiites: insights into the early Earth differentiation processes
}

\author{
AYESHA LANDON-BROWNE ${ }^{1}$, CAROLINE RACHEL \\ SODERMAN $^{2}$, IGOR S PUCHTEL ${ }^{3}$, HEYE FREYMUTH ${ }^{1}$, \\ SIMON MATTHEWS ${ }^{4}$ AND HELEN M WILLIAMS ${ }^{1}$ \\ ${ }^{1}$ University of Cambridge \\ ${ }^{2}$ Department of Earth Sciences, University of Cambridge \\ ${ }^{3}$ Department of Geology, University of Maryland \\ ${ }^{4}$ University of Iceland \\ Presenting Author:arrl3@cam.ac.uk
}

Archean komatiite suites provide a unique window into the composition of the early Earth mantle, planetary differentiation and major mantle melting processes. Komatiite systems from three Archean cratons (Kaapvaal, Superior and the Baltic Shield) present some of the earliest mantle derived samples and document a magmatic record from $3.55-2.41 \mathrm{Ga}$ that can be used to explore secular changes in mantle source region and partial melting processes $[1,2]$.

Iron stable isotopes are a geochemical tool that can be used to explore variations in mantle redox state and source mineralogy [e.g. 3-5]. Importantly, $\mathrm{Fe}$ isotopes are relatively insensitive to the effects of alteration, crustal contamination and late accretion, recent studies suggest that they may even be capable of tracing lower mantle-derived components melting in the upper mantle [6]. We present new Fe isotope data for komatiites from the 3.55 Ga Schapenburg Greenstone Remnant, the 3.48 Ga Komati and $3.26 \mathrm{Ga}$ Weltevreden Formations of the Barberton Greenstone Belt, as well as data from the $2.8 \mathrm{Ga}$ Kostomuksha, $2.72 \mathrm{Ga}$ Boston Creek, and 2.41 Ga Victoria's Lava Lake komatiites [1,2, 7-10]. Our preliminary Fe isotope data indicate that significant differences in $\mathrm{Fe}$ isotope systematics existed between these komatiite systems, providing evidence for $\mathrm{Fe}$ isotope heterogeneity in the early Archean mantle, potentially inherited from core formation and early mantle ocean differentiation processes.

[1] Puchtel et al., (2013) Chemical Geology 262 (3-4), 355369. [2] Puchtel et al., (1996) Contributions to Mineralogy and Petrology 124 273-290. [3] Soderman et al., (2021) GCA. [4] Williams and Bizimis (2014) EPSL 404, 396-407. [5] Dauphas et al., (2014) EPSL. 398, 127-140. [6] Williams et al., (2021) Science Advances in press. [7] Puchtel et al., (2013) GCA 108, 63-90. [8] Puchtel et al., (2013) GCA 108, 63-90. [9] Puchtel et al., (2018) GCA 228, 1-26. [10] Puchtel et al., (2001) EPSL 186, 513-526 